\title{
Matthew's building blocks: Mark and Q - A critical look at a recent monograph
}

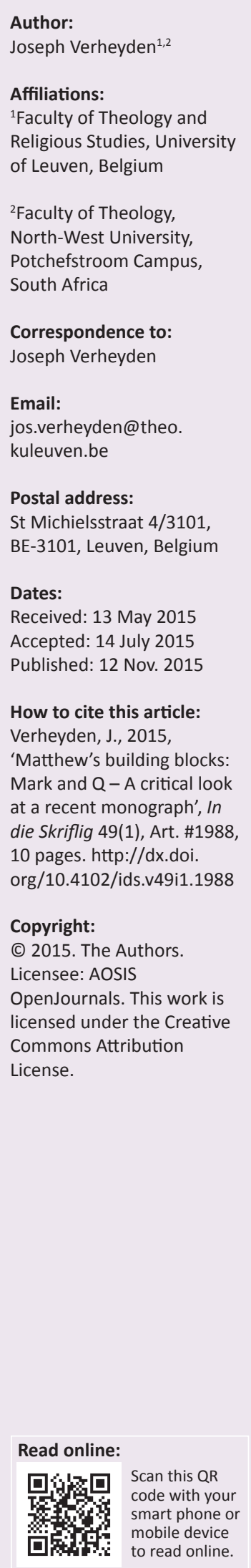

This article offers a critical analysis of some of the principal arguments put forward in a recent monograph by J.A. Doole in defence of the thesis that Matthew, whilst being familiar with Mark and Q, had a clear preference for the former in structuring his composition. Doole argues that Matthew used $Q$ only in such a way that it never threatened to disrupt the dominance of Mark, used up Q 'as quick as possible', and was more at ease in Mark which he used both de visu and from memory. Against these positions, it is shown that $\mathrm{Q}$ played a more prominent roll all throughout Matthew's gospel than Doole assumes it did and that the 'de visu / from memory' dichotomy does not match the evidence.

Matteüs' bouwstenen: Marcus en Q. - Een kritische kijk op een recente monografie. Het artikel biedt een kritische analyse van de voornaamste principes van J.A. Doole's recente monografie ter verdediging van de thesis dat Matteüs weliswaar bekend is met Marcus en met $Q$, maar systematisch de voorkeur geeft aan Marcus. Doole stelt dat Matteüs $Q$ alleen in die zin gebruikte dat het geen bedreiging was voor de dominantie van Marcus, Q zo snel mogelijk 'opgebruikt' heeft, en duidelijk meer vertrouwd was met Marcus die hij de visu en uit zijn herinnering benut. Tegen deze benadering wordt aangebracht dat $Q$ een meer prominente rol speelt in het evangelie dan Doole voorhoudt en dat het onderscheid 'de visu en uit herinnering' niet opgaat.

\section{Introduction}

There are relatively a few topics on which scholars seem to have reached results or conclusions that are shared unanimously. This is true even for such topics that have been studied over a long period of time and by many scholars. It proves the need to keep coming back to issues that some might have thought were solved long ago, which obviously is not the case. One such classic topic that remains so far unsolved is the question of the relationship between the Gospel of Matthew and that of Mark. That Mark was an important source for Matthew is accepted by a large majority of scholars, who take it as the basic framework for studying the question. ${ }^{1}$ The problem, however, is rather more complicated for at least four reasons: firstly, Mark is generally assumed to be only one of Matthew's sources; secondly, there is no absolute agreement on how many sources Matthew has used, nor on what counts as a source; ${ }^{2}$ thirdly, the impact and importance of the various sources in shaping Matthew's Gospel is assessed rather differently by various authors; ${ }^{3}$ and fourthly, it remains a matter of debate precisely how Matthew used Mark and why he did it.

The last point was taken up by Anne M. O'Leary (2006) in her monograph in which she notes that 'the broader examination of how and why he did so did not capture the imagination of scholars', She proposes to read Matthew's role in terms of what she calls a firm (re-)Judaisation of (parts of) his Markan source (O'Leary 2006:2, 118-171; illustrated from several passages from Mt 10 and 18). Other authors have connected this more explicitly, and more polemically, with a reaction on the part of Matthew against Mark's assumed Paulinism (Sim 2002; 2007; 2011; Svartvik 2008). In these approaches Mark is considered to be a major source for Matthew, but one that is in need of substantial reworking in order to make it 'go down' for his own readership and tradition.

\footnotetext{
1.Exceptions are of course such hypotheses that assume Matthean priority, in a relative or absolute way. For the former, see the so-called Multiple-Stage Hypothesis as proposed by inter alia Boismard (1972:11-55; 1990). For the latter, see the (neo-) Griesbach or TwoGospel Hypothesis pleading for Markan posteriority, Farmer (1964; 1990); and the teamwork by Peabody, Cope and McNicol (2002).

2.The origin, profile, and status of Matthew's Sondergut continue to raise discussion. See Foster's (2011) survey of research. A source of a quite different type is the Jewish Scripture (cf. Menken 2004). On the latter issue, see also Konradt (2010).

3.This is not only a problem with regard to the Sondergut material, but also with regard to assessing the influence of tradition and authorial intervention, and the balance between the two in Matthew's redaction of (assumedly) better established sources, like Mark or Q.
} 
In a recent monograph, J. Andrew Doole has broadened the perspective by discussing Matthew's handling of Mark in relation and in comparison to his handling of $Q$, his other major source according to the Two-Source Hypothesis (Doole 2013). Doole fights a war on two fronts. He does not primarily challenge the thesis of Matthew's anti-Pauline (and Mark's Pauline) character, but formulates the issue more generally. Overall, Matthew stays loyal to his major source, which is Mark, and the tradition and views it represents. By the same token he also wishes to contest the views of Ulrich Luz and James Robinson who both have argued, in different ways, that Matthew's Gospel is the result of an attempt by Q Christians to reconcile their own tradition with Mark's after they had come into contact with the latter, most probably following the disaster of the Jewish War and the exodus of Jewish-Christian communities from Judea that resulted from it.

Robinson (1998:124-125, 128) holds that 'Matthew shifts from his loyalty to $Q$ and goes over to subservience to Mark', but does not do so without some resistance and in the awareness that, 'though we will have to do it Mark's way, one can never say we were unfaithful in having done it so long in Q's - and Jesus' - way'. Luz (2011:589) has a somewhat different take on the issue, arguing that when the Q-Matthean community became familiar with Mark's Gospel, it readily noted the differences between the two traditions, yet also remained convinced of their 'fundamental "one-ness"', which led its members to recompose 'their gospel' in line with Mark's and make this Gospel their guide for telling their view on the story of Jesus to the extent that it 'significantly influenced and modified their perspective'.

Over against this (relative) primacy of $Q$ in Matthew's composition, Doole (2013:11) regards Matthew as 'a follower of Mark' and his Gospel as a 'new edition' of Mark's, which he completed with $Q$ that offered him the sayings material he needed to illustrate Jesus' teaching Mark had been talking about. Doole puts it that Matthew shows an 'allegiance to

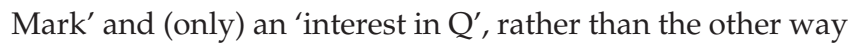
around. Matthew knew and appreciated Mark before he came to use Q. Mark's Gospel is his primary model. Matthew felt free to adopt it according to his way of telling the story by inserting $\mathrm{Q}$ material, which he knew in a written format, as was the case also for his main source. Matthew's reworking of Mark shows both the popularity of the latter's Gospel and the dangers of success, for the 'edition' was such that it incorporated almost all of Mark, to the effect that the latter became redundant and at one point seems to have been at the verge of extinction (2013:21).

The Markan side of the question is also addressed in a recent essay by Matthias Konradt (2013:214-215), who cites Doole (still in the thesis format) but does not make him a major discussion partner. Konradt is critical of the 'anti-Pauline' thesis, but shows quite convincingly from a comparison between Mark's and Matthew's dealing with the torah, Sonof-David Christology, and the position of Jesus' relatives that the latter is indeed critical of his source and wishes to rein in its influence and remedy it to a substantial degree before giving it out to his readers in this new format that is Matthew's Gospel. ${ }^{4}$

In five chapters Doole reviews the sources of Matthew, viz. their extent and form; studies the way Matthew has proceeded in the first and then in the second part of his Gospel; seeks to characterise Matthew as a 'conventional scribe or evangelist'; and evaluates the status of Mark's Gospel for Matthew. In the following it is proposed to have a closer look at some of the arguments Doole has put forward in support of his thesis. More specifically, issue with three of his comments will be taken.

\section{Assessing Mark's influence on Matthew}

Matthew obviously is strongly indebted to Mark's Gospel. He uses it as his literary model and he incorporates most of it, much more than Luke does. Doole (2013) formulates this most clearly in a comment in the final chapter of his book that is worth quoting in full as it reveals something of his approach and viewpoint:

The victory of the narrative over the discourse gospel is of course only evidence for the dominance of the Markan format, not the Markan tradition. Yet here too we have signs that the story of the Gospel according to Mark is central for Matthew. He follows Mark from beginning to end with only brief interruptions for extended discourse and (in)dependent traditions, the omission of a handful of rather minor events in the narrative story, and the rearrangement of a few miracles and the mission of the disciples. Most importantly, however, Matthew's Passion is that of Mark. (p. 176)

This presentation could be said to be basically correct. However, when reading it in its immediate and its broader context one has the impression that Doole does not always seem to be fully aware of its consequences for assessing Matthew's dealing with Mark, that he combines with it some more disputable tenets, and that this formulation creates a tension with other statements. This will be illustrated somewhat further.

By speaking of victory Doole clearly wishes to give the palm to Mark when it comes to decide which of the two, Mark or $Q$, had the larger impact on Matthew. But immediately before this citation one comes across a line that apparently sheds another light on the state of affairs. Matthews shows a preference for Mark over Q. 'Yet Matthew surely respects both his sources, to the extent that he will reproduce and seek to usurp and replace both' (Doole 2013:176). Mark's victory is clearly nuanced in a rather important way. Moreover, respect goes hand in hand with 'usurpation' and 'replacement'. Regardless of how Doole thinks this is to be understood, it

4.Konradt (2013:221-232) and the conclusion: Seine Bearbeitung des Markusevangliums ist ), and the conclusion: Seine Bearbeitung des Jesusgeschichte im Blick auf die Anforderunge Jesusgeschichte im Blick auf die Anforderungen bzw. Bedurfnisse des eigenen Adressatenkreises adäquat neu zu erzählen, sondern auch als Versuch, innerhalb der frühchristlichen Bewegung einer bestimmten Theologie Geltung zu verschaffenund den Einfluss der markinischen Jesusgeschichte zu unterbinden (p. 232). 
obviously casts another light on things and strikes a different chord. It now looks as if there are no winners and that Doole stands closer to such views that are more critical of Matthew's dealing with Mark than he seems to realise or is willing to admit. It is not just a matter of semantics. Victory is something different from replacement.

The lack of clarity or the fuzziness of the vocabulary has consequences. Generally speaking one could say that Matthew 'follows Mark from beginning to end'.

However, Doole seems to belittle the impact of Matthew's intervention in rearranging his Markan material in the first half of his Gospel. Most scholars have been more attentive to this aspect of Matthew's composition than Doole seems to be, and some of them certainly were more concerned about it. Almost all of Mark is saved in that part of the Gospel and Matthew's redaction can be reasonably explained on the basis of Mark, but it consists of more than 'the rearrangement of a few miracles and the mission of the disciples' and its impact is larger than Doole wishes to accept.

Matthew toiled with Mark and the changes are for an important part the result of Matthew's decision to incorporate Q material into the narrative. ${ }^{5}$ There is also another aspect to this question: Doole is critical of scholars who have given up on searching for the overall structure of Matthew's Gospel, as well as of those who think it should be found in the five major discourses. ${ }^{6}$ It is a pity that he does not further develop his views on Mark's impact on Matthew's composition. In particular, one would have liked to read his opinion on the suggestion that Mark's impact was not limited to Matthew following the contents and sequence of his stories, but also included introducing structural markers that would indicate Matthew's dependence on Mark's structure, such as the

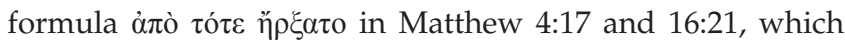
in this view would be a more reliable guiding point than the five-discourse structure for delineating larger sections or entities in Matthew's Gospel. ${ }^{7}$

But perhaps more disturbing still is Doole's assessment of the origin of Matthew's Sondergut material. In his view, Matthew can in no way be credited as its author, not even for smaller additions he introduced to material he picked up from Mark. 'I have continually sought to avoid attributing Matthew's accretions to Matthean creativity' (Doole 2013:177, n. 6.). R.H. Gundry (1994) is cited, and blamed, for upholding the opposite position. Whilst the

5.See the comments of F. Neirynck (1967), one of the most prominent partisans of the view that Mark was Matthew's main guide in composing his Gospel. In commenting on Matthew's 'miracle corpus' in Matthew 8-9, Neirynck (1967:68) notes, 'Le texte de la Quelle ... peut avoir suggéré l'idée d'une série de miracles de Jésus ... Mais c'est $\grave{a} \mathrm{Mc}$ qu'il devait emprunter les récits'. Thus there is a role for $\mathrm{Q}$, even in a section that is thoroughly shaped by Mark and basically consists of Markan material, and even for someone who systematically gave precedence to Mark as the source and inspiration of Matthew.

6.For the first opinion Doole (2013:81) cites Luz (1985:22); for the second he refers to Bauer (1988:35), and the reply by Stanton (2002:62)

7.See Neirynck (1988) in reply to the proposals of J.D. Kingsbury and his student Bauer (1988) latter may at times perhaps have been too adamant in his claims, he certainly also made a good case for Matthean redaction on many an occasion, and he has been rightly applauded for this by others. The reason why Doole refuses to take this path is as revealing as it is disturbing for his position. He admits he just cannot imagine the evangelist, 'a pious early Christian scribe', to have taken to such procedures. It would have been unworthy of his profession, so it seems, and would have degraded him to 'a charlatan and confidence-trickster' (Doole 2013:177, n. 6). This is really harsh language, but in the end one wonders who is most embarrassed by it - the author of Matthew's Gospel, or Doole himself. For indeed, his claims brings the latter in a very difficult situation, as one has to come up with an explanation for the additional material in whatever format. Doole prefers to call these extras 'developments' of Mark's account, but does not speak out on their origin and is content with noting that; overall they do not contradict Mark who remains 'normative' throughout (2013:177). This may all be good and well, but it did not prevent 'loyal' Matthew of adding to the text of Mark, and in doing so, of changing it. Doole prefers to work with an 'unknown' Christian tradition. But what is gained by this, and how does this constitute a better solution than working with the alternative of a known author whose tendencies, and interests, and style, can be identified elsewhere in his Gospel?

\section{Matthew and Q}

Matthew has been struggling to integrate $\mathrm{Q}$ into his Gospel, and so is Doole, it seems, who goes to great lengths to protect the evangelist from yielding too much to the influence of his second source. In this regard two of Doole's observations need to be challenged. He begins by noting, ' $Q$ is not the first major source to be incorporated into the Matthean gospel ..., but it quickly becomes the dominant force' (Doole 2013:69). The first half of this phrase matters little, since Matthew is not citing or using his sources in a strictly subsequent order but rather integrates the two into a new composition of his own. Doole expands on the second half of the phrase just quoted, and adds force to it by citing approvingly Robinson's (perhaps somewhat overstated) observation that 'Mark is hence only a subordinate factor in Matthew 3-11, just as Q is only a subordinate factor in Matthew 12-28' (Robinson 1998:126).

However, after this relatively good start, Doole then tries to minimise Q's influence on Matthew in two ways.

$\mathrm{Q}$ is a force in the first half of the Gospel, but not all the time. In Doole's (2013:70) words, 'The focus on the sayings source $\mathrm{Q}$ is inevitably broken following the Sermon on the Mount'. Also, $Q$ is a force, but it does not affect in any significant way the narrative account as borrowed from Mark. In Doole's (2013) words:

it [Matthew's dealing with $Q$ ] will have only minimal effect on the firmly established account of the life of Jesus as taken from Mark, begun in Mt 3 but followed faithfully from Mt 12. (p. 70) 
The first of these observations is the weaker, hence also the easier to refute. Doole's is a rather unfortunate expression. I am not sure what he means with inevitably, but the change of focus after the Sermon is in any case not final and actually short-lived, as Doole (2013:68) readily admits when noting 'in the mission discourse the focus is still clearly on $Q$, and this will become even more potent in what follows', and when labelling the miracle section in Matthew 8-9 'an interlude of narrative activity' (2013:70), thereby further disqualifying his initial statement. The focus on $Q$ is not broken, it is suspended for a short while after Matthew $5-7$, and then most forcefully resumed in the latter part of Matthew 3-11.

As for Doole's second observation, it is true, of course, that Matthew hardly leaves out anything from Mark and indeed basically also keeps intact the overall sequence of the events that are related by Mark. But Mark's account is affected in other ways by incorporating material from $\mathrm{Q}$ into the first half of the Gospel. This happens at three levels.

Firstly, Matthew may have kept to the structure of Mark's account, but he has given it content with the help of $\mathrm{Q}$. His second source provides him with the material to add flesh to the bones and to transform Mark's account into a much longer and richer one that directs the reader beyond Mark. There may be not much to be found in $Q$ about the Baptist's location, but the larger part of what should be said about the contents of his preaching comes from Q (3:7-10, 12) or has a parallel in $Q$ which Matthew does not hesitate to call upon to alter or complete Mark's version (3:11). Q is less prominently present in the account of Jesus' baptism (maybe because it was so close to Mark), but it massively steps in again right after to inform the reader of what actually happened in the desert. So, Q has claimed its place, much to the benefit of the reader, at the same moment as Mark does and completes the latter in a significant way. The import of Q material in Matthew's account of the Baptist and the temptation narrative did perhaps not turn upside down the Markan framework and story line, but by filling it up with new content it took away some of its preponderance, and it definitely also shifted the balance between the various elements of that framework (the extensive temptation narrative). But there is more in play than adding content to Mark.

Secondly, with the help of $Q$, and maybe also under its influence, Matthew performs a major transformation of the order in which Mark had presented Jesus' activities.

Doole (2013:69) notes, 'rather than begin with Mark's miracles, Matthew takes the reference to "teaching" in Mk 1:21-22 and begins Q's sermon'. That sounds as if Matthew caused a major breakup of Mark's framework. And this is indeed how one should best describe Matthew's intervention. But perhaps Doole's is also somewhat incorrect or too simplistic in his presentation of what Matthew has been doing with that framework. Mark does not 'begin with miracles'. He starts his account of Jesus' ministry in Galilee with a short and general statement on the contents of his teaching (Mk 1:14b-15). He picks up on this motif and develops it in what follows by introducing an audience people hearing Jesus preach at a Sabbath service in the synagogue (Mk 1:21-22) - and by describing the effects his person and teaching have on the audience - some start following Jesus, others are impressed and wonder about the origin of his power. But nothing is said anymore about the contents of the teaching. Instead Mark turns to Jesus' healing ministry that is illustrated in much detail all through the rest of chapter 1 and up to the first pericope of chapter 2. It is only briefly interrupted by two passing references to teaching that again tell the reader nothing about its content (Mk 1:3839, the latter together with healing). Matthew follows Mark 1:14-15 in Matthew 4:13-17, though not without clarifying the setting on the basis of Mark 1-21a (par. Mt 4-13a) and accounting for it by a long citation from Scripture (Mt 4:14, 15-16). He decidedly drops all the concrete information on the healing activity (obviously without saying he will come back to it later). Instead he keeps to some general summary references to Jesus' healing activity without instancing this in any concrete way, as is clear from the summary account in Matthew 4:23-25. In v. 23, Jesus' teaching and healing are combined, as if equally important, as they are in the parallel in Mark 1:39.

But contrary to Mark, the content of the first one is illustrated, however briefly, by recalling a phrase from Matthew 4:17, whilst the second is formulated in a rather more general way (not exorcisms, but all sorts of healings). A first attempt at illustrating the healing activity somewhat further is made in Matthew 4:24-25, but it all still remains quite general compared to what the reader by then had found in Mark. Matthew's summary in v. 24-25 is largely tributary to Mark, using elements from Mark 1:28.32-34 and 3:7-13 (cf. Neirynck 1990). The final verse of this latter passage provides Matthew with the setting for the Sermon (Mt 5:1 par Mk 3:13a).

One cannot say that the healing motif is completely absent from this part of Matthew and that the evangelist solely focuses on the teaching. But when it comes to illustrating these activities Matthew resolutely choses to give precedence to the latter and only then will turn to the former. One may perhaps dispute whether this intervention constitutes a radical change in the sequence of events, as both activities are mentioned from the outset and supposed to be an integral part of Jesus' ministry, but on the level of the narrative it produces a significant change as the reader's attention is first and foremost drawn to Jesus' teaching. That is the Jesus that Matthew's readers first come to know more intimately.

It is probably an exaggeration to say that $Q$ 'forced' Matthew to intervene in Mark's order in such a (drastic) way. But at least $\mathrm{Q}$ allowed him to do so, providing him with ample material for illustrating the contents of Jesus' teaching in far 
more detail than he had found so far in Mark and also for significantly changing the contents. ${ }^{8}$ Jesus teaches and heals, but as Matthew sees it, he teaches first. As a matter of fact, the whole composition of Matthew leading up to and including the Sermon on the Mount could be called 'Mark in reverse'. The latter told how Jesus was teaching all over the place, but hardly showed an interest in its content and instead started telling details about his healing ministry. Matthew, by contrast, says that Jesus was teaching and healing, but then first tells the reader extensively, what Jesus had to say, and only then moves on to illustrate Jesus 'the miracleworker'. Mark influenced Matthew, but he did not dominate him. Matthew mentions both aspects of Jesus' ministry, as did Mark (and Q). They are of equal importance, but when it comes to telling the reader about them, it seems that one is more equal than the other. We are talking about a change of perspective that, on the level of the narrative, involves a change in sequence; and it is obvious who is 'to blame' for it.

Thirdly, Q has also influenced the sequence of events as narrated by Matthew on a smaller level. Two instances will be mentioned briefly. Mark has the Baptist being killed whilst the disciples are on their first mission. He uses the episode to fill the gap that is left by the disciples' absence. It makes for an elegant composition (Mk 6:7-13, 14-16, 17-29, 30). Matthew has deconstructed it. He separates the two and anticipates the mission instructions, placing it at a much earlier point (in Mt 10). $Q$ is nowhere in sight, but it nevertheless may have played its part in this. After Jesus' encounter with the Baptist, Mark mentions John only once, in the controversy on fasting in Mark 2:18 (indirectly, through a reference to his disciples), before then telling about his death in Mark 6:14-16, 17-29. It looks as if in between all links with the Baptist have been severed; he is no factor in Jesus' ministry and is never mentioned again by him. Matthew has a parallel to these two passages of Mark (9:14 and 14:1-2, 3-12), but he then also has Jesus speaking at length about the Baptist in Matthew 11:7-19, following the latter's inquiry about Jesus' identity in 11:2-6. This is Q territory. Matthew could have had Jesus speaking of the Baptist in the same, or a very similar way, also after the latter's death, but instead prefers to bring this passage at an earlier stage, when John is still around. One cannot say that he did so because he wished to remain true to Mark's order and make the account of his death the last thing to be told about the Baptist, for that is not the case. John is mentioned a couple more times later on in Mark (and in Matthew), be it briefly: Mark 8:28 par Matthew 16:14; Mark 11:30, 32 par Matthew 21:25-26; Matthew has additional references in 17:13 and 21:32. When Matthew then decides to

\footnotetext{
8.Indeed, if Mark 1:14-15 gave the impression that it touched upon core elements of Jesus' teaching, it really only 'touched upon' them and evoked a picture of a rather Baptist-like Jesus. Matthew loosens the Baptist's grip and there appears much richer and more complete (and complex) picture of Jesus' teaching. Matthew

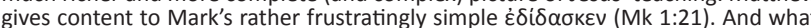
a content! The reader is treated to nothing less than a detailed account of Jesus' a content! The reader is treated to nothing less than a detailed account of Jesus' 'programmatic discourse', something one will look for in vain in Mark. Q provides the lion's share, ' $M$ ' does most of the rest, and Mark is reduced to a figurant who may occasionally have inspired (or spoiled) Matthew's rephrasing of a $Q$ saying. This happens marginally at Matthew 5:13, 15 par with Mark 9:49-50 and Matthew 4:21 more directly at Matthew 5:(29-)30 par with Mark 9:43, 45, though Matthew seem to have changed the wording wherever he could; possibly at Matthew 7.2 par with Mark 4:24; and only remotely possibly at Matthew 5:23-24 par with Mark 11:25. It is only in the conclusion, itself not part of the discourse, that Mark steps forward again (Mt 7:28b-29 par 1:22)
}

insert a substantial extra passage with valuable information on John and Jesus before telling about the former's death, he does not really change the sequence of events that he found in Mark, but he nevertheless intrudes upon that sequence and has Jesus making a statement about John that is directly relevant for his teaching and his own position. One should at least concede that he thought the $Q$ material to be sufficiently important and pressing to be given a place in Jesus' earliest ministry of which there is no trace in Mark.

The second example has to do with the status Doole gives to Matthew 11:5 and how he uses it for assessing Matthew's composition in chapters 8-9. That status is said to be ambivalent, and the way Doole presents it, this is certainly true. In an attempt to give body to the Isaiah citation Matthew turns to Mark for help. In so far as this was an obvious choice, there is nothing wrong or surprising about it. But then Doole wanders off and misses the point. He claims that the citation was after all not that important to Matthew: 'The role of the Q logion in determining this series of miracles is not to be overstated' (Doole 2013:71). Proof for this is found in the way Matthew has proceeded. When confronted with what is said in Q 7:22 and what he finds in Mark, Matthew does not hesitate to give precedence to Mark and also includes such healing activities that are not even mentioned in Q. I would like to dispute this presentation. If it really was an issue for Matthew to match $\mathrm{Q}$ with Mark at this point, he could have done a far better job. Now it rather looks as if he is caught between two loyalties - to Mark and to Q, and has struggled in vain to accommodate both. There were several other options besides the one he has taken.

He could have dropped the Q saying (he must have known Q 7:22 is not a faithful rendering of Isaiah), he could have adjusted it to Mark's information (he drops the demoniac of Mk 1:23-28 - no such healing is mentioned in Q - but then he keeps the Gerasene demoniacs, and even doubles them!), or he could have gone the opposite way and choose from Mark only such passages that illustrate Q 7:22. He does none of these, but shows the reader the blatant differences that exist between the two.

One way to get around this, is by concluding that Mark's account was so 'dominant' Matthew did not wish to leave out an iota, but that does not work, for he left out some of the healing stories. Another option is to accept the situation and blame Matthew for it, making him a careless author. There is, however, also a third option, and that is to allow Matthew to be aware of the tensions and to have him make sense of it. It might well be the safer one. What Matthew does is praise Mark, and praise Q, by keeping both of them on board. But then he also goes on adding two $\mathrm{Q}$ healing stories to his Markan material, and this at strategic places, namely in Matthew 9:32-34, at the very end of the section in which he had been catching up on Jesus' healing ministry as told by Mark, and in Matthew 8:5-13, as the second in his series of healing stories, thereby 'breaking up' Mark's arrangement even further than merely by inverting some pericopes, as 
he also does in Matthew 8-9. Q 7:22, by contrast, is kept intact (there is an almost $100 \%$ agreement with Luke). In short, Matthew wishes the reader to be confronted with the tensions; and that makes sense - especially also on the terms we are discussing here. Mark's 'full' account is (implicitly) said to be not-so-final or perfect; it has been rearranged by Matthew himself, and Q adds further material for a composition that is different from Mark's. The issue is not that Q does not comply to Mark's order and therefore would show its 'submission' and Mark's 'domination', but rather that Matthew, by keeping it intact, shows $Q$ to have a value of its own, just as the healing summary of Matthew 4:24-25:2 was composed with little consideration for Mark's structuring of the healing stories. Indeed, in a sense, $Q^{\prime}$ 's is the 'definite' summary, the one that is found 'worthy' to summarise all of Matthew 8-9 when Jesus informs the Baptist about his healing ministry. That is quite a different status, not subservient to, but along and on an equal level with Mark, and perhaps even slightly more important than Mark, as this summary follows after the whole healing ministry had been told in so much detail. It means that the importance of this 'only lull in the dominance of Mark', as Doole (2013:72) labels Q's influence on the miracle section, is to be taken more seriously than the qualification might evoke: another voice is heard besides Mark's in this section and elsewhere in the first half of the Gospel, and it sounds loudly.

Doole (2013) also develops a second type of argument for reducing the influence of $Q$ on Matthew's composition by stating:

That $\mathrm{Q}$ is thus almost confined to the first half of Matthew's gospel is often taken as evidence of Matthew's affiliation to the $\mathrm{Q}$ teaching, which is itself permeated with M traditions. However, as $Q$ is almost exhausted halfway through Matthew's gospel and as it fails to exert significant influence on the reception of Mark in Matthew, we have to ask how close Matthew really is to $Q$. If he were representative of a $\mathrm{Q}$ community, he may understandably take to writing his gospel with the incorporation of $\mathrm{Q}$ traditions as his first project. Yet once finished this, would a self-respecting Q-Christian resort to rote copying of the gospel of Mark, and leave no Q stamp on the Markan account? (p. 69)

Doole makes it look as if $\mathrm{Q}$ were almost an embarrassment to Matthew, something he was trying to 'masquerade' and dispose of as quickly as possible, before turning all his attention to his 'really important' source again.

That $Q$ would not have left its stamp has been discussed and rejected above. That in Matthew it was 'permeated with $\mathrm{M}$ traditions' is a bit of a nasty phrase, if put like that with no further explanation. Of course, such things have happened, but Mark has been 'permeated' in the same way (see Mt 3:15-16 or 14:28-31), and Matthew has permeated Mark with $\mathrm{Q}$ material on an even larger scale. The question is what instigated Matthew to this intervention and for what purpose this happened. Was it because Matthew thought $\mathrm{Q}$ (or Mark) were somehow 'incomplete', or was this actually inspired in a more positive way by what he read in either $\mathrm{Q}$ or Mark?
I am not sure how we can ever determine what 'a selfrespecting Q-Christian' coming across Mark and seeing its value could or should have done with that part of Mark that does not invite or allow for adding $Q$ material. It is hard to imagine that there was something in $\mathrm{Q}$ forbidding an author to go beyond it. As far as we can possibly know, $\mathrm{Q}$ did not say it was a closed corpus of sayings of Jesus, nor did it speak out against telling stories about Jesus' passion and trial (it rather seems to suppose these) or against using narrative material (it seems to have started doing this itself). ${ }^{9}$

Doole's description of Matthew's handling of $Q$ is contradictory and indeed also false. It is contradictory for two reasons. Doole notes the massive presence of $\mathrm{Q}$ in the first half of the Gospel, and then is surprised that nothing is left. But that seems to be plainly obvious. One cannot eat one's cake and have it. $Q$ is a source of wisdom, but it is not an eternally flowing source. Moreover, Doole emphasises this presence of $\mathrm{Q}$, but nevertheless concludes from it that it cannot be used to demonstrate that this source was of any special importance to Matthew. It is also false, again for two reasons. Actually, Matthew uses both $Q$ and Mark abundantly in the first half of his Gospel. They both must have been close to his heart. So this is 'undecided'. Moreover, Matthew has not 'used up' Q in Matthew 3-11 to the extent that Doole wishes the reader to believe. There is still quite some $\mathrm{Q}$ material left for the second half - in any case more than Doole seems to have detected when covering the material in Mathew 12-28. Indeed, his survey of Matthew's dealing with Q in the second part of his Gospel is both inaccurate and incomplete. He discusses only a selection of passages. A couple of these are Mark-Q overlaps, others instances in which Matthew has worked a $Q$ verse into Mark, but such passages in which he relies more heavily or even exclusively on $\mathrm{Q}$ in this latter part of his Gospel are just left unmentioned, even though they also involve Matthew struggling with Q and with Mark (Mt 23, part of 24 and 25). ${ }^{10}$

\section{Matthew and Mark}

In developing a parallel strategy for arguing that Mark is Matthew's primary source and building block, Doole looks for evidence that Matthew was thoroughly familiar with Mark's Gospel. It is not said that he was more so than with $\mathrm{Q}$, but in the light of what was said on $\mathrm{Q}$ that is obviously the conclusion the reader is invited to draw. Doole (2013) says:

Mark is his starting point, his basis, his familiar ground, and if indeed he is concentrating on his $\mathrm{Q}$ traditions in the early part of his gospel, he does not always need to consult Mark directly,

\footnotetext{
9.Several of the Gospels show the same kind of (relative) 'openness'. John concludes his Gospel by saying that 'more could have been told'; Luke begins his by informing the reader that there apparently are other accounts around, and then goes his own way; Mark richly distributes summaries all over the first half of his Gospel, which are like invitations to add more such material to what has been told about Jesus' preaching and healing activities. None of them uses formulas that exclude adding to or dropping from their content, as sometimes can be found in other texts.

10.In all, Doole briefly touches upon seven passages, and for reasons unknown to me does so in a random order: Mark 3:28-30 par Matthew 12:31-37; Mark 9:28-29 par Matthew 17:19-20; Mark 8:11-13 par Matthew 16:1-4; Mark 9:40 par Matthew 12:30a; Mark 4:10-12 par Matthew 13:10-17; Mark 7:14-17 par Matthew 15:10-15; Mark 10:23-31 par Matthew 19:27-30. I cannot possibly go Matthew 15:10-15; Mark 10:23-31 par Matthew 19:27-30. I cannot possibly go
into the details, but just wish to note that Doole in this part does not once mention the work of Fleddermann (1995).
} 
and may recall the Markan tradition either from memory alone or from notes. In doing so, he is liable not only to 'abbreviate' the detail of the Markan tradition but to colour the account with his own language and concerns. He joins Mark for Jesus' baptism and journey to Caphernaum [sic], yet he then enjoys a certain flexibility with regard to the Markan arrangement of the early miracle accounts. So he is to some extent free to place Markan content without its original Markan context. (p. 51)

Matthew's free handling of Mark as described by Doole is taken as an indication of his familiarity with the source, and thereby also tacitly excused. But the same would go for Matthew's dealing with $Q$ and should then lead to the same conclusion. One element of Doole's description warrants special attention. It is the suggestion that Matthew used Mark 'from memory' or 'from notes'. Taking the healing section in Matthew 8-9 as his test case, Doole argues that Matthew at first most probably had visible contact with Mark 1, though it cannot be firmly established whether he really relied on the text of Mark itself $(8: 2-4,14-17) .{ }^{11}$ Then he would have reproduced his source without having direct access to it (Mk 8:18-27, 28-29:1a). ${ }^{12}$ At one point, however, he did return to the text proper (Mk 9:1b-8, 9-17), ${ }^{13}$ but soon left it again (Mk 9:18-26 and then also at 9:27-31, 32-34). ${ }^{14}$ Doole cites approvingly W.C. Allen's hypothesis that Matthew would not have troubled to open his copy of Mark when moving from Mark 1:40-45 (par Mt 8:2-4) to Mark 4:35ff. (par Mt 8:18ff.), but then again had 'eye contact' with the source when returning to Mark 2:1-12, 13-17, 18-22 in Matthew 9:1-8, 9-13, 14-17. 'In view of the brevity of Matthew as compared with Mark. ... it seems not improbable that when the editor came to Mark 1:45 and was proposing to pass on to Mark 4:35-5:20, he did not unroll Mark's Gospel to these verses, but summarised them from memory' (Allen 1951:84, as quoted by Doole 2013:59). ${ }^{15}$ There are several problems with this presentation.

Firstly, Allen's formulation is not fully accurate. Matthew does not move directly from Mark 1:40-45 to 4:35ff. In between he also harked back to Mark 1:29-31, 32-34 (par. Mt $8: 14-15,16-17)$ for which he may have had 'eye contact'.

Secondly, the suggestion does not explain why Matthew would not have cared to turn back to the source, or why he would have cared to do so at any given moment, since he apparently felt himself to be sufficiently 'familiar' with Mark to rewrite him 'without Mark', that is without having the text before him.

11.Doole (2013:55) hesitates, speaks of 'no real need', but also says 'Mark is apparently open at Mark 1, and he may consult Mark concerning either or both accounts', and concludes by citing Derrenbacker's 'It is possible to assume ... visual contact' (cf. Derrenbacker 2005:253)

12.Stronger evidence' and Matthew using Mark 'apparently without feeling the need to consult his copy for a direct reproduction' (Doole 2013:55).

13.Matthew will pick up where he left off in his copy of Mark' (Doole 2013:59).

14.Again ... he will recall an episode from the Markan tradition' (Doole 2013:62).

15.See also the similar citation from Allen (1951:95) in Doole (2013)

It is certainly noticeable that the sections in which Matthew is considerably shorter than Mark, viz., Mark 4:35-41; 5:1-20, 21-43, are just those to obtain which the editor must be supposed to have unrolled his copy of Mark if he wished to see them before him.
Thirdly, and most importantly, the argument does not work and is contradicted by the evidence. Reading Allen, it appears that the sole indication for concluding that Matthew at times used Mark from memory would be the brevity of his account.

Matthew abbreviates more drastically when he has no eye contact with the text of Mark. One conclusion that should be drawn from this observation is that Matthew is apparently less familiar with Mark than Doole wants him to be, for if Mark is not immediately around Matthew misses out on a good part of his source. But there is more, for the argument itself is flawed. Brevity is the key, but on looking closer into the material, it turns out that there are no significant differences in this respect between such pericopes that Matthew would have rewritten with an eye on Mark and those that he rewrote from memory according to Doole. Here is the evidence. In 8:2-4 Matthew probably used Mark's version of the healing of the leper in 1:40-45 de visu. He reduces the 99 words of Mark by almost half to 52 and adds nothing of his own. ${ }^{16}$ Matthew 8:14-17 gives similar numbers. Mark 1:29-34 counts 90 words, which Matthew brings back to 48 , but now he adds a whole verse of 18 words (v. 17). But in Matthew 8:18-27, working from memory, the numbers are 118 against 85 , hence a far less drastic abbreviation! Here too Matthew adds a substantial extra (from Q) for a total of 70 words (8:19-22). The numbers may be more impressive for the next passage that is supposed to have been composed without an eye on Mark. The 346 words of Mark 5:1-21 (it is not a bad option to include also this last verse) are reduced to 140 in Matthew 8:28-29:1a, less than half of the original and including two verses that have no direct parallel in Mark $(8: 28 b, 34)$. But in Matthew 9:1b-8, with Mark in front of him, Mark's 196 words for 12 verses (2:1-12) are reduced to 121 for 8 verses, with only some small extras without a parallel in Mark in the last verse. In the next double pericope (Doole takes Mk 2:13-22 par. Mt 9:9-17 as one section), with Mark in sight, the numbers are almost equal and there are no significant additions or omissions. The reduction is most massive in Matthew 9:18-26 par Mark 5:22-43, where Matthew is supposed to have lost direct contact again, but by now it should be clear that brevity as such is not exclusively characteristic of this kind of pericopes. ${ }^{17}$ So it is not just about brevity and counting works; maybe other factors are also in play.

Could it be that the type of changes, and the reason for these, play a role? Three types of changes should be mentioned, namely rewriting, omissions, and additions. In 8:2-4, Matthew hardly touches on the sayings material,

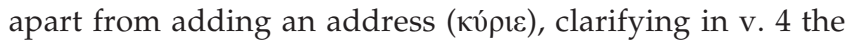

16.The counts are based on Doole's presentation of the parallels (cf. Doole 2013: 53-68), which in some cases is open to discussion.

17.The last two pericopes of this whole healing section are of a somewhat different nature. In the first Matthew did not turn back in Mark but looked forward (Mt 9:27-31 par Mk 10:46-52, with maybe also a few elements from Mk 8:22-26 echoing through), at least if one is prepared to see influence of Mark here echoing through), at least if one is prepared to see influence of Mark here,
something Doole wishes to dispute arguing instead that this is Sondergut material (Doole 2013:65). The final pericope, Matthew 9:32-34, is an overlap text. 
subject (Jesus) and the object that is to be brought (a gift), and dropping a redundant negation. He drops the whole of v. 45 , the double reference to Jesus' mood in verses 41 and 43 , and the slightly awkward way in which Mark tells the reader that the man was healed (v. 42), for a total of 38 words. And he drastically reformulates and reduces the opening verse ( 13 vs. 7 words), keeping only the word $\lambda \varepsilon \pi \rho$ ó $\varsigma$, crucial for the story, but he does not really change the scene: it is still about a man coming and kneeling before Jesus and asking to be healed. Most, indeed all of the changes can be 'easily explained' on theological or stylistic grounds (cf. the explanations in Doole 2013:53). But the same seems to be true for his handling of Mark 4:35-41 in Matthew 8:18-27, for which he would not have had eye contact. The rewriting is mild and largely synonymous, includes the removal of some redundancies, or otherwise inappropriate minor elements, and contains some Matthean stylistic features, but it is not significantly different from that in Matthew 8:2-4 and it does not offer any indication that it came about because Matthew had no longer eye contact with Mark. So nothing has been proven so far.

In 8:28-29:1a Matthew strikes heavily from his 'absent' source without adding anything substantial instead, but he does the same in Matthew 9,1b-8 and now he is supposed to have returned to Mark. He also strikes a lot in Matthew 9:18-26, supposedly without directly relying on Mark, but now adds a verse of his own at the end. Mathew 9:26 is not only most appropriate in view of the following pericope (in 9:27-31 Jesus is known when he passes by), but it also has its closest parallel in Mark 1:28, the conclusion of a passage that Matthew has not taken over. However, this verse and pericope is not immediately in sight at 9:26 and Matthew formulates it quite differently, even though it contains two words that he uses elsewhere and that would perfectly fit the context, which might be taken as proof that he is more shaky in rendering Mark 'by heart' than Doole supposes him to be.

Finally, adding an extra verse is in itself hardly proof that Matthew was working on his own. He does so in 9:26, but basically because it creates the necessary link to add on another pericope in which the recognition of Jesus is a crucial element. In 8:19-22 he inserts a long passage from $Q$ in his parallel to Mark 4:35-41. It adds drama to what follows as the disciples show a surprising lack of faith and courage to follow Jesus right after he had taught them about this topic, but it does not alter the focus of the passage and there is no reason to think that Matthew would have 'dared' to make this change because Mark was out of sight (which, it must be said, Doole is not suggesting). He also adds verse 17 to his rewriting of Mark 1:29-34, which introduces a typically Matthean interest. In this instance Doole (2013:54) ponders on the possibility that it may indicate that Matthew can reproduce this tradition without the need to consult his copy of Mark at all at this point'. But again there is no reason to think that Matthew would not have dared to make such a move with Mark in front of him, especially not if we should assume that he knew Mark so well. Moreover, this passage may well have been written in direct contact with Mark (see above).

It seems then that the only reason left to assume that Matthew at times did not take the trouble to go and look up Mark would be the fact that he would have to browse back in his copy. But how difficult or impossible would that have been in the case of Matthew 8-9? If it can be assumed that Matthew had reached Mark 3:7-13 when inserting the Sermon on the Mount; he is supposed to have gone back to his source for its conclusion (Mt 7:28-29 par Mk 1:21-22) and probably also for the next pericope (Mt 8:2-4 par Mk 1:40-45), as we have seen, though not at the point where he had left it, but much earlier in Mark and by connecting two passages that do not follow each other in his source. ${ }^{18}$ It does not mean that he randomly plunged into Mark and had missed out on some of the healing material that preceded Mark 1:40-45, for he uses this right after. It must mean that Matthew was consciously searching his source for such material that he wished to bring together into this one grand section he had in mind and that he was reordering it rather sovereignly, but not necessarily without eye contact. If Matthew 8:14-15, 16-17 are supposed to have been composed in direct contact with Mark, Matthew did return to another place in Mark than where he had left his source, to insert the healing of the centurion's servant. So Matthew was indeed browsing through the source. As he was focusing on Jesus' healing ministry, Matthew saw no point in following up with Mark 1:35-38. The summary of Mark 1:39 had been used in Matthew 4:23. But it remains to explain why Matthew moved all the way to Mark 4:35-41, which is not a healing story, instead of first continuing with Mark 2:1-12 that was nearby. A plausible reason might be that Mark 1:32-34 is a summary account of Jesus' healing ministry that is also nicely rounded off at 1:34. It would be rather strange to have this followed by another healing story. Matthew rephrases the conclusion but at the same time strengthens its character by introducing the citation from Isaiah 53:4. Immediately adding another story of the healing of an individual would be rather strange. So, in a sense, Mark 'forced' Matthew to go looking for a way to continue the section and the focus on healing, but with a brief interlude, which, however, would not really introduce something completely different. The overall focus should stay on miracle working, and Mark also offers the solution with 4:35-41, and indeed gives Matthew an opportunity to continue telling about the healing activity. Moving from Mark 1:34 to 4:35 was not a difficult or impossible move. It offered itself. Of course Matthew could have picked out Mark 4:35-41 and then gone back to Mark 2:1-12 and resume the healing stories in the order in which they occur in Mark, but the setting and the motif of traveling the sea rather invited following up Mark 4:35-41 with 5:1-20. Mark 2:1-12 instead introduces a different venue. Mark's conclusion of the healing of the Gadarene demoniac, with the people urging Jesus to leave, required a new setting. Mark offers it in 5:21, but in fact it is

18.The situation is somewhat different if Mark $1: 21-22$ is taken to be the main (sole) hinge to insert the Sermon, but even then Matthew was supposed to have gone back in his source to continue at Matthew 8:2-4. 
'more of the same', as Jesus is on a boat again. A rather more new venue, with a lot of potential, is found in Mark 2:1-12 when Jesus is said to move to his hometown. Jesus had been out there on the sea, and even in Transjordan, but now he is home again. Matthew picks up and continues the list of healing stories with Mark 2:1, duly reminding the reader that Jesus is home ('his own city'). Mark will be his companion for the next three pericopes, two of which are, as for their genre, not really healing stories, though healing (of a kind) definitely is a topic in both of them as can be seen from the saying in Matthew 9:12 and, though in a more metaphorical way, perhaps also from the emphasis on giving up on the old (9:16-17). After that Mark again invites looking elsewhere.

There follows another healing story in Mark 3:1-6, in the second next pericope, but Matthew leaves that for later and instead opts to return to Mark at the point where he had left him and which should not have been too difficult to locate. The choice offers him a nice opportunity to create a tension between the disciples of John and Jairus and an anonymous woman who go at great length to receive help from Jesus instead of starting to quarrel with him. But Matthew has kept the largest leap for last. For the first of the two final passages of this whole cycle, he jumps forward to Mark 10:46-52, only to leap back again to Mark 3:22! This move is so amazing that it takes Doole aback and has him conclude that here Matthew had completely given up on looking for inspiration in Mark. I think such a conclusion is not necessary, but if one opts for the alternative, one should note that Matthew is perhaps his (and our) best proof that he was able to wander around in his source. It proves that he is thoroughly familiar with it; it does not prove he walked around blindly. ${ }^{19}$

\section{Conclusion}

Matthew has worked with Mark and with $Q$ to compose his Gospel, and he has continued to do so all through his Gospel, or almost so, up to and including chapter 25. Throughout, Mark constitutes the backbone of the narrative, in part because $\mathrm{Q}$ offers nothing in this respect. But the second source adds flesh to the bones, and does so abundantly. In this process, at times it not also influences the form and format the story is told, but also has some effect on the sequence, without, however, disturbing the latter in any drastic way. Matthew is familiar with both of his sources to a degree that it has become impossible to conclude that he must have belonged to the Markan tradition (community) and cannot have belonged to the tradition (community?) that gave us Q. Some may find this a frustrating conclusion; others can live, or have learned to live with this kind of uncertainty.

Finally, even if Matthew only wished to be true to Mark and had no intention to change its structure, he must have realised that his handling of Mark, through Q, was short of giving a

19. Needless to add, I do not wish to argue that Matthew could only have had access to Mark through visual contact. Obviously, an author who was so familiar with his source, as was Matthew, must also have had part of his source 'im Kopf. My point is rather, in dialogue with Doole, that it is difficult, almost impossible, to say where he did so and where he did not. fatal blow to the model. And actually that is what happened, for in the second century Mark virtually disappeared, only to be rescued by Irenaeus, but even then it never came close to Matthew in exercising influence on later authors.

\section{Acknowledgements Competing interests}

The author declares that he has no financial or personal relationship(s) that may have inappropriately influenced him in writing this article.

\section{References}

Allen, W.C., 1951, A critical and exegetical commentary on the Gospel according to S. Matthew, 3rd edn., Clark, Edinburgh.

Bauer, D.R., 1988, The structure of Matthew's Gospel: A study in literary design, JSOT Press, Sheffield. (JSNT Sup 31).

Boismard, M.-É., 1972, Synopse des quatre évangiles en français, vol. 2, Cerf, Paris.

Boismard, M.-É., 1990, 'The multiple stage hypothesis', in D.L. Dungan (ed.), The interrelations of the Gospels: A symposium led by M.-É. Boismard, W.R. Farmer, F. Neirynck, Jerusalem 1984, pp. 231-288, University Press \& Peeters, Leuven. (Bibliotheca Ephemeridum Theologicarum Lovaniensium 95).

Derrenbacker, R., 2005, Ancient compositional practices and the synoptic problem, Peeters, Leuven. (Bibliotheca Ephemeridum Theologicarum Lovaniensium 186).

Doole, J.A., 2013, What was Mark for Matthew? An examination of Matthew's relationship and attitude to his primary source, revised version of a PhD thesis, University of Marburg, 2011, dir. F. Avemarie, Mohr Siebeck, Tübingen. (Wissenschafliche Untersuchungen zum Neuer Testament 2/344)

Farmer, W.R., 1964, The synoptic problem: A critical analysis, Macmillan, New York.

Farmer, W.R., 1990, 'The two-gospel hypothesis: The statement of the hypothesis', in D.L. Dungan (ed.), The interrelations of the Gospels: A symposium led by M.É. Boismard, W.R. Farmer, F. Neirynck, Jerusalem 1984, pp. 125-156, University Press \& Peeters, Leuven. (Bibliotheca Ephemeridum Theologicarum Lovaniensium 95).

Fleddermann, H.T., 1995, Mark and Q: A study of the overlap texts, University Press \& Peeters, Leuven. (BETL 122).

Foster, P., 2011, 'The M-source: Its history and demise in biblical scholarship', in P. Foster et al. (eds.), New studies in the synoptic problem: Oxford Conference, April 2008 - Essays in honour of Christopher M. Tuckett, pp. 591-616, Peeters, Leuven (BETL 239).

Gundry, R.H., 1994, Matthew: A commentary on his handbook for a mixed church under persecution, 2 nd edn., Eerdmans, Grand Rapids.

Konradt, M., 2010, 'Die Rezeption der Schrift im Matthäusevangelium in der neueren Forschung', TLZ 135, 920-932.

Konradt, M., 2013, 'Matthäus und Markus: Überlegungen zur matthäischen Stellung zum Markusevangelium', in P. von Gemünden et al. (eds.), Jesus - Gestalt und Gestaltungen: Rezeptionen des Galiläers in Wissenschaft, Kirche und Gesellschaft; Gestaltungen: Rezeptionen des Galilaers in Wissenschaft, Kirche und Gesellschaft; Festschrift fur Gerd Theissen zum 70. Gebur
Ruprecht, Göttingen. (NTOA/StUNT 100).

Luz, U., 1985, Das Evangelium nach Matthäus, Benziger, Zürich. (EKK 1.1).

Luz, U., 2011, 'Looking at Q through the eyes of Matthew', in P. Foster et al. (eds.), New studies in the synoptic problem: Oxford Conference, April 2008 - Essays in honour of Christopher M. Tuckett, pp. 571-590, Peeters, Leuven. (Bibliotheca Ephemeridum Theologicarum Lovaniensium 239).

Menken, M.J.J., 2004, Matthew's Bible: The Old Testament text of the evangelist Peeters, Leuven. (Bibliotheca Ephemeridum Theologicarum Lovaniensium 173).

Neirynck, F., 1967, 'La rédaction matthéenne et la structure du premier évangile', in I. de la Potterie (ed.), De Jésus aux évangiles: Tradition et rédaction dans les évangiles synoptiques, pp. 41-73, Duculot, Gembloux. (Bibliotheca Ephemeridum Theologicarum Lovaniensium 25).

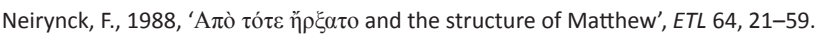

Neirynck, F., 1990, 'Matthew 4:23-5:2 and the Matthean composition of 4:23-11:1', in D.L. Dungan (ed.), The interrelations of the Gospels: A symposium led by M.É. Boismard, W.R. Farmer, F. Neirynck, Jerusalem 1984, pp. 23-46, University Press \& Peeters, Leuven. (Bibliotheca Ephemeridum Theologicarum Lniversity Press \&
Lovaniensium 95).

O'Leary, A.M., 2006, Matthew's judaization of Mark examined in the context of the use of sources in Graeco-Roman antiquity, Clark, London. (LNTS 323).

Peabody, D.B., Cope, L. \& McNicol, A.J. (eds.), 2002, One gospel from two: Mark's use of Matthew and Luke-A demonstration by the research team of the International Institute for Gospel Studies, TPI, Harrisburg.

Robinson, J.M., 1998, 'The Matthean trajectory from Q to Mark', in A. Yarbro Collins (ed.), Ancient and modern perspectives on the Bible and culture: Essays in honor of Hans Dieter Betz, pp. 122-154, Scholars, Atlanta. (Scholars Press Homage Series 22). 
Sim, D.C., 2002, 'Matthew's anti-Paulinism: A neglected feature of Matthean studies', HTS Teologiese Studies / Theological Studies 58, 767-783. http://dx.doi. org/10.4102/hts.v58i2.557

Sim, D.C., 2007, 'Matthew 7.21-23: Further evidence of its anti-Pauline perspective', New Testament Studies 53, 325-343. http://dx.doi.org/10.1017/ S0028688507000161
Sim, D.C., 2011, 'Matthew's use of Mark: Did Matthew intend to supplement or to replace his primary source?', New Testament Studies 57, 176-192. http://dx.doi. org/10.1017/\$0028688510000366

Stanton, G.N., 2002, The Gospels and Jesus, 2nd edn., Oxford University Press, Oxford.

Svartvik, J., 2008, 'Matthew and Mark', in D.C. Sim \& B. Repschinski (eds.), Matthew and his Christian contemporaries, pp. 27-49, Clark, London. (LNTS 333). 